\title{
46. CARBONATE DIAGENESIS IN CORES FROM SITES 438 AND 439 OFF NORTHEAST HONSHU, NORTHWEST PACIFIC, LEG 57, DEEP SEA DRILLING PROJECT
}

\author{
Ryo Matsumoto and Azuma Iijima, Geological Institute, University of Tokyo, Tokyo, Japan
}

\begin{abstract}
Petrographic and mineralogical studies using optical and scanning electron microscopes and X-ray diffraction and X-ray microprobe analyzers on 137 samples of Pleistocene to Upper Cretaceous sediments at Sites 438 and 439 off northeast Honshu in northwest Pacific yielded the following major results:

1) Sites 438 and 439 are characterized by carbonate-free terrigenous and diatomaceous sediments throughout the Pleistocene to the Upper Cretaceous. However, carbonate concretions, thin limestone beds, and carbonate-cemented sandstones are sporadically intercalated. Moreover, terrigenous and diatomaceous sediments occasionally contain significant amounts of carbonates.

2) Carbonate minerals encountered include calcite, dolomite, ankerite, and siderite. Calcite and dolomite are either of authigenic or detrital origin. Biogenic calcite grains are not uncommon. Ankerite and siderite are of detrital origin.

3) Authigenic calcite ranges in chemical composition from high $\mathrm{Mg}$ calcite in the Pleistocene sediments to Fe calcite in the uppermost Oligocene sediments through FeMg calcite in the Miocene sediments. Composition is probably controlled by diagenetic alteration of initially precipitated high $\mathrm{Mg}$ calcite during burial.

4) $\mathrm{Mg}$ ions released from high $\mathrm{Mg}$ calcite during the transformation seem to cause dolomitization.

5) The transformation and dolomitization in the uppermost Oligocene sandstone were probably accelerated by the recharge of fresh or brackish water from the underlying subaerially formed conglomerate and/or from the nearby Oyashio ancient landmass.
\end{abstract}

\section{INTRODUCTION}

Cores from Sites 438 and 439 on the inner trench slope about $160 \mathrm{~km}$ east of Hachinohe, northeast Honshu (Figure 1), range in age from Pleistocene to Upper Cretaceous. They are characterized by carbonate-free, fine- to coarse-grained terrigenous and diatomaceous sediments. However, they yield sporadic carbonate concretions, thin limestone beds, marl, and carbonatecemented sandstones. The carbonate rocks are composed mostly of calcite, but some of them, especially from the uppermost Oligocene, contain significant amounts of dolomite and ankerite. Moreover, siderite clast was recognized, though only one such clast occurred in all the samples. Aragonite was not detected.

In this chapter we describe carbonate sediments and rocks of various types; carbonate minerals of terrigenous-detrital, bioclastic, and authigenic origin are discriminated on the basis of the petrographic texture, mineralogy, and chemical composition of carbonates. Diagenetic alteration of authigenic carbonates and the origin of dolomite are also discussed.

\section{METHODS}

Semiquantitative X-ray diffraction analysis was made on all samples - 100 from Site 438 and 37 from Site 439 - by a RIGAKU GF-2013 diffractometer with Ni-filtered, $\mathrm{CuK} \alpha$ radiation of $35 \mathrm{kV}$ and $15 \mathrm{~mA}$ and scanning speed of 2 degrees $2 \Theta / \mathrm{min}$. Stratigraphic horizons are shown in the right-hand column of Figure 2. Percentage of constituent carbonates were read on calibration curves from the peak heights of $d_{104}$ reflection. Special diffraction patterns of 25 samples were taken with a scanning speed of 0.5 degrees $2 \Theta / \mathrm{min}$., adding silicon powder as an internal standard, in order to get precise $d_{104}$ spacing of carbonates.

Thin section analyses were made on 16 samples to observe textural relation of carbonates. Calcite was stained with alizarin red in order to distinguish it from dolomite. Volume percentage of detrital and authigenic carbonates was measured under a microscope, using a point counter.

$\mathrm{Au}-\mathrm{Pd}$ and carbon-coated, fresh-fractured surfaces of 6 samples were scanned with a HITACHI HSM-2 


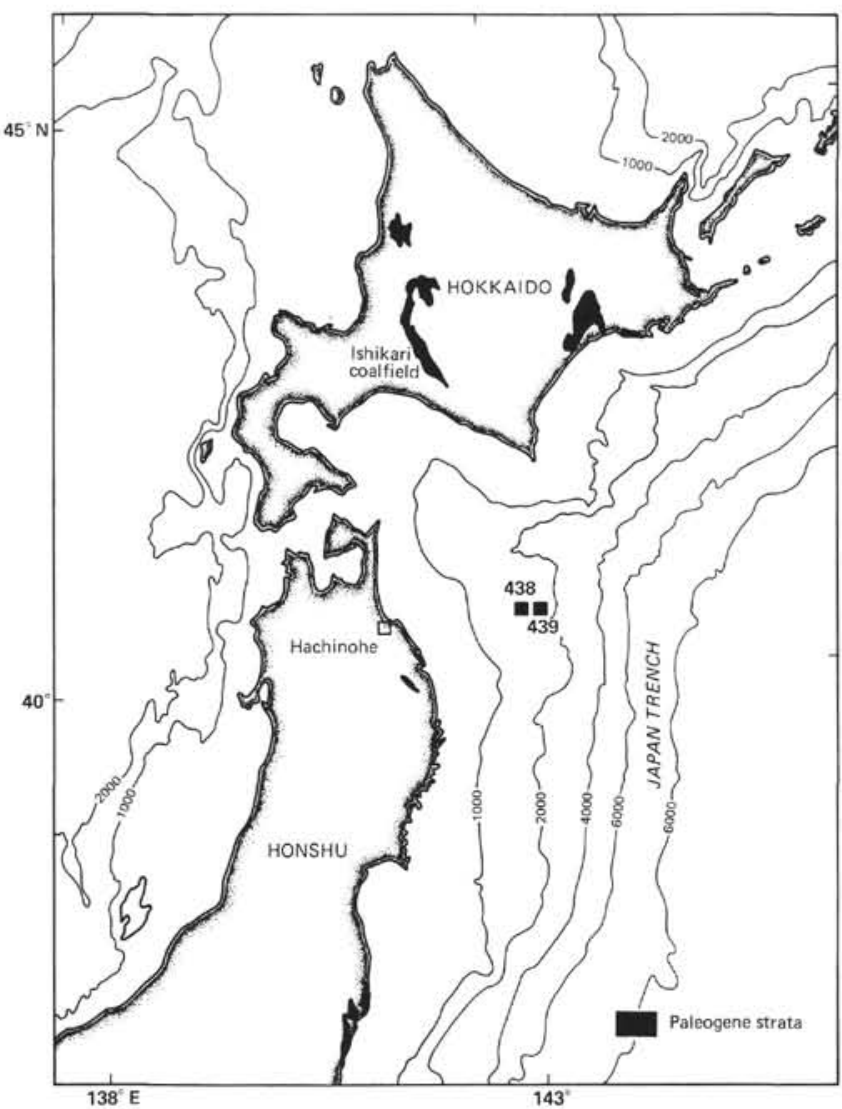

Figure 1. Location of Sites 438 and 439 of Leg 57 and distribution of Paleogene strata in northeast Japan.

scanning electron microscope (SEM) at $100 \mu \mathrm{A}$ to observe microtextures.

Quantitative chemical analyses of $\mathrm{Ca}, \mathrm{Mg}, \mathrm{Fe}$, and $\mathrm{Mn}$ in carbonate minerals were carried out on 9 carboncoated samples with a Japan Electron Optics JXA-5 $\mathrm{X}$-ray microanalyzer (XMA). Accelerating voltage was $15 \mathrm{kV}$ and sample current was 0.010 to $0.015 \mu \mathrm{A}$ on periclase. Electron beam diameter was $3 \mu \mathrm{m}$ on specimen. Standard samples were prepared from carbonate minerals with homogenous chemical composition. The correction for absorption fluorescence, ionization, and backscattering effects were collectively made by the method of Bence and Albee (1968).

\section{DISTRIBUTION OF CARBONATE SEDIMENTS ${ }^{1}$}

Carbonate minerals were detected in 29 samples by a bulk X-ray diffraction analysis. They are distributed throughout the cores and range in age from the Pleistocene to the Upper Cretaceous. However, the frequency and the mode of occurrence of carbonate sediments are variable among different stratigraphic horizons, as shown in Figure 2.

\footnotetext{
1 "Carbonate sediments" is applied in this chapter to those sediments and rocks containing enough carbonates to be detected with an X-ray diffractometer.
}

Pleistocene and Pliocene diatomaceous clay and sandy clays deposited in a lower middle bathyal environment are scarce in carbonates as a whole, except for the calcareous sandy clay in Sample 438A-3-6, 134-136 cm, and light gray marly diatomaceous ooze of Sample 438A- 26-3, 60-62 cm. Upper Miocene sediments are also poor in carbonates. Middle Miocene diatomaceous claystone deposited in a lower middle bathyal environment contains intercalated carbonate sediments at several horizons. They occur either as light gray to light brownish gray indurated micritic limestone beds, generally less than $10 \mathrm{~cm}$ thick, as in Samples 438A-60-1, 94$96 \mathrm{~cm}, 438 \mathrm{~A}-68-2,45-47 \mathrm{~cm}$, and $439-5-2,8-10 \mathrm{~cm}$, or as light brownish gray marl, as in Sample 438A-60-2, $32-35 \mathrm{~cm}$. Lower Miocene diatomaceous claystone and vitric sandy claystones with sporadic turbidite sandstone contain light gray micritic limestone or marl, as in Samples 438A-21-4, 112-114 cm, and 439-11,CC, and light brownish gray calcareous silty claystone, as in Sample 439-13-2, 68-70 cm.

Uppermost Oligocene medium- to fine-grained sandstone, deposited in an upper bathyal to surf zone environment, is common to abundant in carbonate rocks. It occurs either as light gray carbonate-cemented sandstone, as in Samples 439-28-3, 124-125 cm, and 439$30-1,10-12 \mathrm{~cm}$, or as porous calcareous sandstone, as in Samples 439-30-3, 15-18 cm, 439-31-4, 43-45 cm, and 439-32-1, 99-101 cm. Carbonates of subaerial origin in the uppermost Oligocene dacitic conglomerate were not investigated. Upper Cretaceous sandy claystone contains only a slight amount of calcite, which replaces clastic silicate grains.

\section{X-RAY MINERALOGY AND TYPES OF CARBONATE SEDIMENTS}

Percentage of calcite in carbonate sediments is mostly below $25 \mathrm{wt}$. per cent but rarely reaches $47 \mathrm{wt}$. per cent, as shown in Figure 3. Calcite content of the Plio-Pleistocene carbonate sediments ranges from 3 to $21 \mathrm{wt}$. per cent and averages $8 \mathrm{wt}$. per cent. Those of the Miocene and Oligocene average 19 wt. per cent. "Dolomite"' is rare in fine-grained sediments from the Pleistocene to the Miocene but rather common in the uppermost Oligocene sandstone. "Dolomite" content is less than $8 \mathrm{wt}$. per cent and averages $5 \mathrm{wt}$. per cent. The $d_{104}$ spacing of calcite varies widely $(2.995-3.037 \AA)$, as shown in Table 1 and Figure 2 . The $d_{104}$ spacing of "dolomite," ranging from 2.901 to $2.919 \AA$, is always considerably larger that that of the end member dolomite $(2.886 \AA)$. Sample 438-28-3 has the largest value of $d_{104}$ spacing among the Oligocene samples.

Carbonate sediments in the Pleistocene clay to the Miocene claystone can be divided into two types on the basis of the value of $d_{104}$ spacing. One type is characterized by calcite with nearly end member value of $d_{104}$ spacing (Type A). The other contains calcite of smaller

\footnotetext{
${ }^{2}$ For convenience, dolomite-ankerite series that forms a continuous solid solution is often expressed collectively as "dolomite."
} 

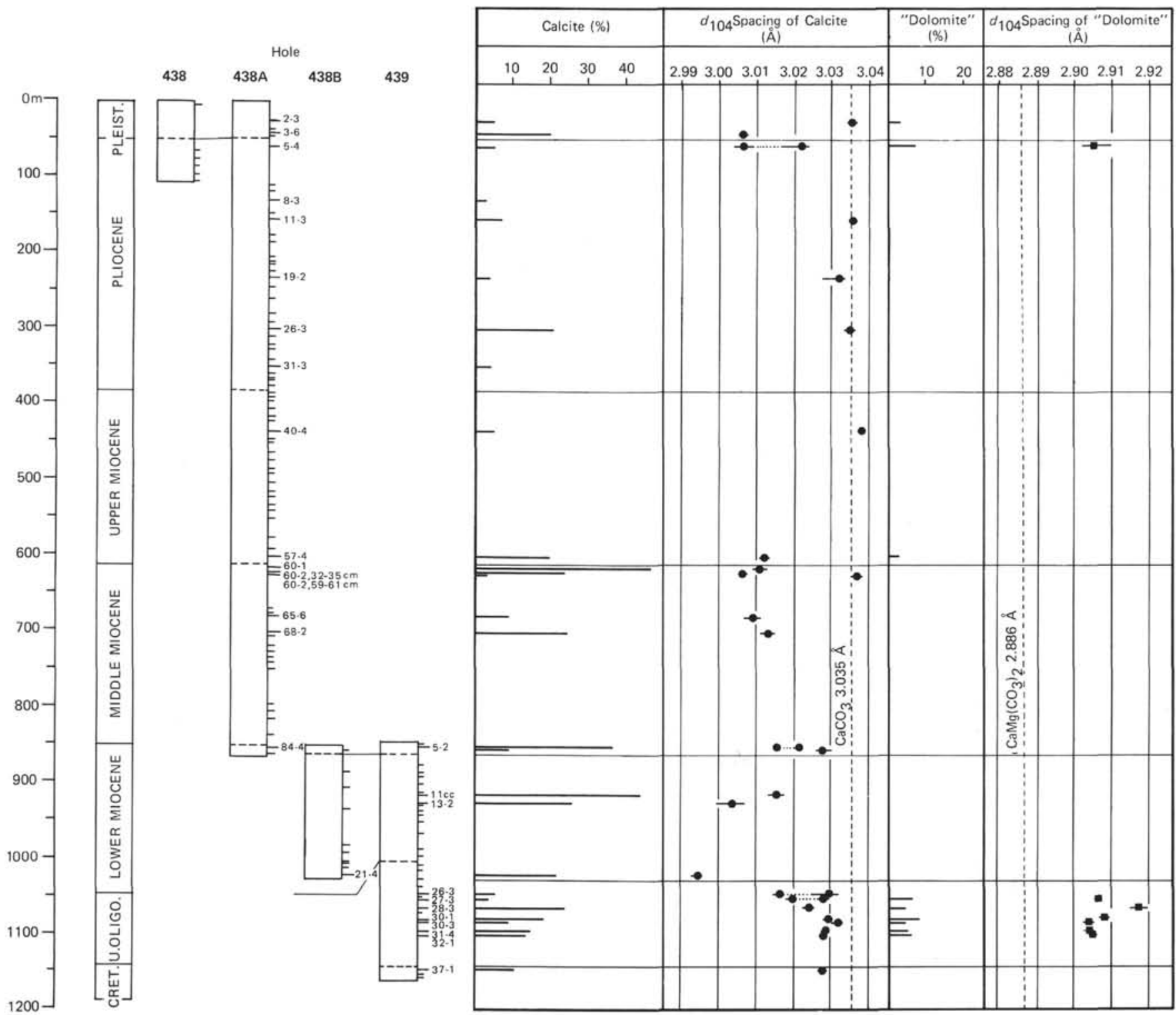

Figure 2. Stratigraphic horizons, distribution of carbonate sediments, and percentage and $\mathrm{d}_{104}$ spacing of carbonate minerals. Geologic ages and correlation are according to shipboard scientific results. Broken tie lines appearing in $\mathrm{d}_{104}$ spacing of calcite indicate double peaks.

$d_{104}$ spacing than the end member value (Type B). Type A carbonate sediments generally contain small amounts of carbonate-within a range of 3 to 21 per cent and averaging 8 per cent. Type B carbonate sediments contain relatively large amounts of carbonates-within a range of 5 to 47 per cent, averaging 25 per cent (Table 1). Type $A$ and Type $B$ carbonate sediments range in age from Pleistocene to lower Miocene, but Type B tends to concentrate in the middle and lower Miocene (Figure 2).

Calcite in uppermost Oligocene sandstone shows an intermediate value of $d_{104}$ spacing between the two types. It is often associated with significant amounts of "dolomite," in contrast with Types A and B, which consist principally of calcite. Hence uppermost Oligocene carbonate-cemented sandstones are grouped into a separate type (Type C).

\section{MICROTEXTURES OF CARBONATE SEDIMENTS AND ORIGIN OF CARBONATE CONSTITUENTS}

\section{Carbonates in Pleistocene Clay through Miocene Claystone}

The Type A carbonate sediments always contain a few per cent or more calcareous tests of foraminifers which are usually well to moderately preserved. Authigenic calcite is also present, replacing clastic silicate grains, glass shards, or siliceous skeletons; however, it occurs in very small amounts. Thin section analysis failed to reveal the texture or the origin of calcite grains in Sample 438A-26-3, 60-62 cm, which has an exceptionally high calcite content, with nearly end member value of $d_{104}$. However, SEM observation revealed that this sample contains a significant number of coccoliths 


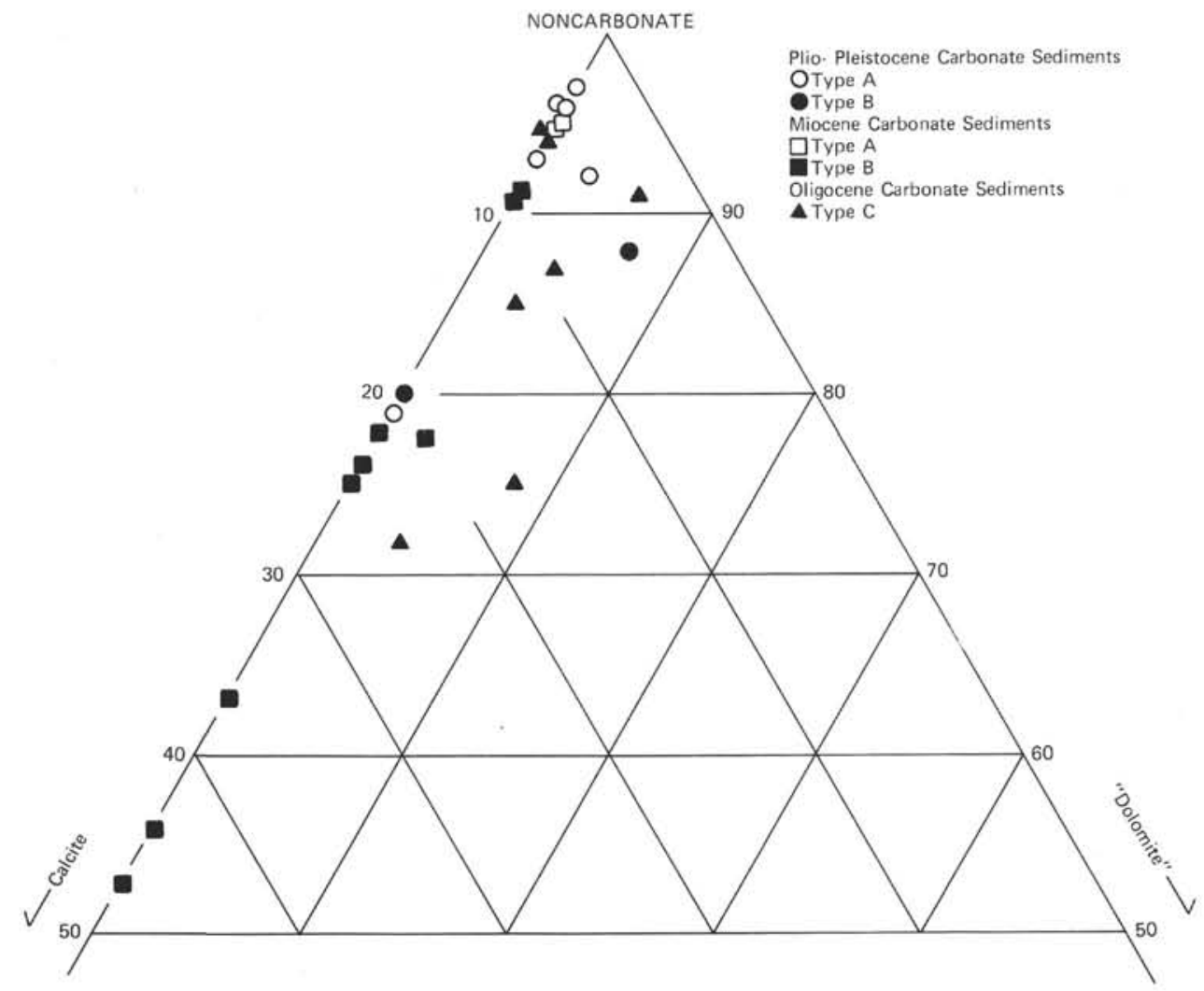

Figure 3. Ternary plot of calcite, "dolomite," and the remaining minerals (mainly detrital silicates) of carbonate sediments. Compositions from X-ray data. Carbonate content is generally less than 25 per cent in carbonate sediments, which are composed of nearly end member calcite.

TABLE 1

Types of Carbonate Sediments and Origin of Carbonate Constituents

\begin{tabular}{|c|c|c|c|c|c|c|}
\hline \multirow{2}{*}{$\begin{array}{l}\text { Type of Carbonate } \\
\text { Sediments }\end{array}$} & \multirow{2}{*}{$\begin{array}{c}\text { Sample } \\
\text { (Interval in } \mathrm{cm} \text { ) }\end{array}$} & \multirow{2}{*}{$\begin{array}{c}\text { Carbonate Content } \\
\text { calcite and "dolomite" } \\
\text { (wt. \%) }\end{array}$} & \multirow{2}{*}{\multicolumn{2}{|c|}{$d_{104} \underset{(\AA)}{\text { Spacing of Calcite }}$}} & \multicolumn{2}{|c|}{ Carbonate Constituents $(\mathrm{A}=$ abundant, $\mathrm{C}=$ common, $\mathrm{R}=$ rare $)$} \\
\hline & & & & & calcite & "dolomite" \\
\hline Type A & $\begin{array}{l}438 A-2-3,30-32 \\
438 A-11-3,60-62 \\
438 A-19-2,40-42 \\
438 A-26-3,60-62 \\
438 A-40-4,90-92 \\
438 A-60-2,59-61 \\
438 A-84-4,126-128\end{array}$ & $\begin{array}{rc}7 & \\
7 & \text { Range: } \\
4 & 3-21 \\
21 & \\
5 & \text { Average: } \\
3 & 8 \\
9 & \end{array}$ & $\begin{array}{l}3.035 \\
3.036 \\
3.032 \\
3.035 \\
3.037 \\
3.036 \\
3.028 \\
\end{array}$ & $\begin{array}{l}\text { Range: } \\
3.028-3.037 \\
\text { Average: } \\
3.034\end{array}$ & $\begin{array}{l}\text { (A) Biogenic: Planktonic and } \\
\text { benthic foraminifers } \\
\text { and coccoliths } \\
\text { (R) Authigenic: Replacing } \\
\text { glass shards }\end{array}$ & (R) Detrital (?) \\
\hline Type B & $\begin{array}{l}438 A-3-6,134-136 \\
438 A-5-4,106-108 \\
438 A-57-4,143-145 \\
438 A-60-1,94-96 \\
438 A-60-2,32-34 \\
438 A-65-6,45-47 \\
438 A-68-2,24-26 \\
438 B-21-4,112-114 \\
439-5-2,8-10 \\
439-11, C C \\
439-13-2,68-70\end{array}$ & $\begin{array}{rr}20 & \\
5 & \\
22 & \\
47 & \text { Range: } \\
24 & 5-47 \\
9 & \\
25 & \text { Average: } \\
18 & 25 \\
37 & \\
44 & \\
26 & \\
\end{array}$ & $\begin{array}{l}3.006 \\
3.006(-3.022) \\
3.012 \\
3.011 \\
3.006 \\
3.009 \\
3.013 \\
2.995 \\
3.015(-3.021) \\
3.015 \\
3.004\end{array}$ & $\begin{array}{l}\text { Range: } \\
2.995-3.015 \\
\text { Average: } \\
3.008\end{array}$ & $\begin{array}{l}\text { (A) Authigenic: Bladed and } \\
\text { anhedral microcrystalline } \\
\text { calcite } \\
\text { (R) Biogenic: Foraminifers and } \\
\text { calcareous algae }\end{array}$ & (R) Authigenic (?) \\
\hline Type C & $\begin{array}{l}439-28-3,124-125 \\
439-30-1,10-12\end{array}$ & $\begin{array}{l}29 \text { Average: } \\
25 \quad 27\end{array}$ & $\begin{array}{l}3.024 \\
3.029\end{array}$ & $\begin{array}{l}\text { Range: } \\
3.016-3.030\end{array}$ & $\begin{array}{l}\text { (A) A uthigenic: Sparry calcite } \\
\text { cement } \\
\text { (R) Detrital: Micritic limestone } \\
\text { clasts }\end{array}$ & $\begin{array}{l}\text { (A) Authigenic: Rhombohedral } \\
\text { dolomite cement } \\
\text { (C) Detrital: Zoned rhombohedral } \\
\text { "dolomite" clasts }\end{array}$ \\
\hline s. & $\begin{array}{l}439-26-3,5-7 \\
439-27-3,28-30 \\
439-30-3,15-18 \\
439-31-4,43-45 \\
439-32-1,99-101\end{array}$ & $\begin{array}{lc}6 & \text { Range: } \\
11 & 6-21 \\
14 & \text { Average: } \\
21 & 14 \\
20 & \end{array}$ & $\begin{array}{l}3.016-3.030 \\
3.020-3.029 \\
3.032 \\
3.029 \\
3.028\end{array}$ & $\begin{array}{l}\text { Average: } \\
3.027\end{array}$ & $\begin{array}{l}\text { (A) Detrital: Micritic limestone } \\
\text { clasts and sparry calcite } \\
\text { (C) Authigenic: Sparry calcite } \\
\text { cement } \\
\text { (R) Biogenic: Molluscs }\end{array}$ & $\begin{array}{l}\text { (A) Detrital: Zoned rhombohedral } \\
\text { "dolomite" clasts }\end{array}$ \\
\hline
\end{tabular}


and foraminifers as well as diatoms and sponge spicules (Plate 2, Figures 1 and 2). A test of planktonic foraminifer is usually made up of low $\mathrm{Mg}$ calcite, 0.4 to $0.6 \mathrm{~mol}$. per cent $\mathrm{MgCO}_{3}$ (Milliman, 1974). Coccoliths are considered to be low Mg calcite; dissolved carbonate portions of coccolith ooze are poor in $\mathrm{Mg}$, with less than $1.8 \mathrm{~mol}$. per cent $\mathrm{MgCO}_{3}$ (Thompson and Bowen, 1969). Thus carbonate sediments composed chiefly of foraminifers and/or coccoliths reasonably represent the nearly end member value of $d_{104}$ spacing of calcite. Hence Type A carbonate sediments are considered to be composed principally of biogenic calcite.

The optical microscope and SEM show that Type B carbonate sediments in the Pleistocene section are composed of bladed crystals of authigenic calcite (Plate 2, Figures 3 and 4). Bladed crystals are 8 to $22 \mu \mathrm{m}$ in the longest diameter and 3 to $6 \mu \mathrm{m}$ in the shortest diameter, sometimes representing crystal twins in the cement of Jamaican reefs (Land and Goreau, 1970). They closely resemble scalanohedral high $\mathrm{Mg}$ calcite. They usually fill interstices of vitric sandy clay but rarely replace glass shards. Type B carbonate sediments in the Pliocene and Miocene sections do not have such a bladed calcite but usually contain subhedral or irregular shaped polyhedral grains. This is probably because of the neomorphism of bladed calcite cement during burial. The double reflection at $d_{104}$ spacing of calcite in several samples can be attributed to a mixture of biogenic and authigenic calcites or to exsolution of high $\mathrm{Mg}$ calcite.

\section{Carbonates in Uppermost Oligocene Sandstone}

Calcite occurs in various forms such as sparry cement, replacement of clastic silicate grains, limestone clasts, and calcareous shell fragments. "Dolomite" occurs as rhombohedral cement, replacement of clastic grains, and detrital grains.

Samples 439-28-3, 124-126 cm, and 439-30-1, 10-12 $\mathrm{cm}$, are well-indurated lithic arenites composed chiefly of subangular medium-sized grains of acidic volcanic rock, carbonaceous mudstone, plagioclase, quartz, chert, and siliceous shale in that order of abundance, with a small amount of clay matrix. These samples are cemented with sparry calcite, which frequently fills clusters of adjacent pores up to $0.4 \mathrm{~mm}$ across. The sparry calcite usually includes authigenic rhombohedral "dolomite" of 55 to $80 \mu \mathrm{m}$ in the longest diameter, resulting in a poikilitic textures (Plate 1, Figures 1 and 2). SEM shows that authigenic "dolomite" rhombohedra are well crystallized, fresh in appearance, and often contain crystal twins (Plate 2, Figure 5). A second type of "dolomite" occurs in the form of rhombohedra 15 to 30 $\mu \mathrm{m}$ across, replacing(?) only the clasts of chert and siliceous shale and not other components of the sandstone. This suggests that the chert and siliceous shale contained "dolomite" prior to deposition. Detrital calcite such as subangular micritic limestone and sparry calcite clasts are not uncommon, forming up to 3 per cent by volume.

Samples 439-30-3, 15-18 cm, 439-31-4, 43-45 cm, and 439-32-1, 99-101 cm, belong to lithic graywacke (Pettijohn et al., 1972) and differ from Samples 439-28-
3 and 439-30-1 in petrographic texture and mode of occurrence of carbonates. They are made up chiefly of subangular coarse- to fine-sized grains of chert, siliceous shale, carbonaceous mudstone, acidic volcanic rock, quartz, and plagioclase. They are characterized by the common occurrence of detrital "dolomite" as well as detrital calcite. Detrital "dolomite" occurs in the form of rhombohedral or subhedral grains of 64 to 220 $\mathrm{mm}$ across, more or less broken or weathered (Plate 2, Figure 6). It is sometimes associated with syntaxial calcite cement. Detrital calcite grains are subangular to subround and of a similar size to other clastic grains. Besides detrital "dolomite" and calcite, only one detrital siderite grain $110 \mathrm{~mm}$ across was recognized (Sample 439-32-1, 99-101 cm). Detrital carbonates amount to 5 to 8 per cent by volume in the aggregate. Sparry calcite cement and "dolomite" rhombohedra replacing(?) chert and siliceous shale are also present; however, they occupy only 1 and 0.5 per cent by volume, respectively. Articulated molluscs, sparsely included in sandstone, are the third constituent of calcite. But they are not present in quantity.

We conclude from the microtextures that the $d_{104}$ spacings of calcite and "dolomite" in Samples 439-30-3, 439-31-4, and 439-32-1 represent mainly detrital carbonates. Those of Samples 439-28-3 and 439-30-1 can be attributed to authigenic calcite and "dolomite." The double reflections at $d_{104}$ spacing of Samples 439-26-3 and 439-27-3 may reflect the mixture of authigenic calcite and biogenic calcite of pelecypods, because pelecypods are usually of aragonite or low $\mathrm{Mg}$ calcite in living condition and these samples contain fragmental pelecypods. The three types of carbonate sediments and the origin of carbonate constituents are summarized in Table 1.

\section{CHEMICAL COMPOSITIGN OF CALCITE AND DOLOMITE}

\section{Authigenic Calcite}

Bladed calcite cements of the Pleistocene sediments are revealed to be high $\mathrm{Mg}$ calcite, containing 88.0 to 89.0 mol. per cent $\mathrm{CaCO}_{3}, 10.5$ to 11.5 mol. per cent $\mathrm{MgCO}_{3}, 0.3$ to $0.6 \mathrm{~mol}$. per cent $\mathrm{FeCO}_{3}$, and less than 0.1 mol. per cent $\mathrm{MnCO}_{3}$ (Figure 4). Some of the previous analyses of recent calcite cement on the sea floor record a $\mathrm{MgCO}_{3}$ content of 5.5 to $7.5 \mathrm{~mol}$. per cent in Mediterranean limestone crust and about 13 mol. per cent in the buff limestone layer off Barbados (Fischer and Garrison, 1967), $18.5 \mathrm{~mol}$. per cent in the scalanohedral calcite cement of the Jamaican reefs (Land and Goreau, 1970), 13 to $18 \mathrm{~mol}$. per cent in Mediterranean beach rock cement (Alexandersson, 1972), 8 to 12 mol. per cent in fine-grained calcite within the deep sea bottom sediments of the eastern Mediterranean (Milliman and Müller, 1973), and 15 mol. per cent in ooids from the Great Barrier Reef (Marshall and Davies, 1975). The analyses in the present study fall in the intermediate range of the previous data, closely resembling those of the eastern Mediterranean deep sea sediments. 


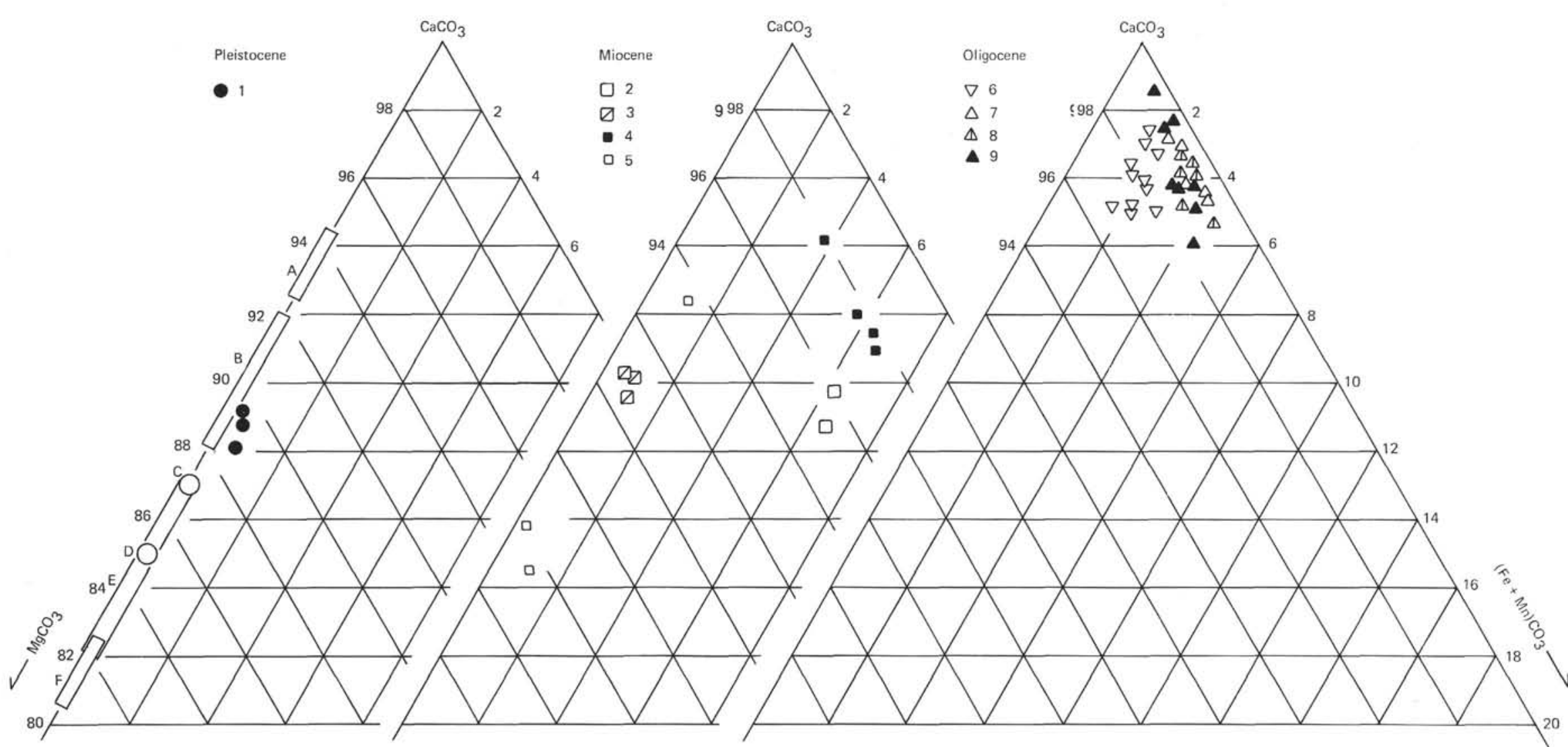

Figure 4. Chemical composition of authigenic calcite, represented in mol.per cent. $\mathrm{MnCO}_{3}$ content is generally less than 0.3 mol. per cent (1. Sample 438A-3-6, 134-136 cm; 2. 438A-60-1, 94-96 cm; 3. 439-5-2, 8-10 cm; 4. 439-11, CC; 5. 438B-21-4, 112-114 cm; 6. 439-28-3, 124-125 cm; 7. 439-30-3, 15-18 cm; 8. 439-31-4, 43-45 cm; 9. 439-32-1, 99-101 cm. A-F: Previous analyses of recent high Mg calcite cements and ooids precipitated from sea water. $A=$ Mediterranean limestone crust [Fischer and Garrison, 1967], B = fine-grained Mg calcite within deep sea sediments of the Eastern Mediterranean [Milliman and Müller, 1973], C = buff limestone bed off Barbados [Fischer and Garrison, 1967], D = high Mg calcite ooids from the Great Barrier Reef [Marshall and Davies, 1975], $E=$ Mediterranean beachrock cement (Alexandersson, 1972), $F=$ scalanohedral calcite cement of the Jamaican Reef [Land and Goreau, 1970].) 
Fine-grained calcite cements of the Miocene sediments have a wide range of chemical composition as 84.5-94.0 mol. per cent $\mathrm{CaCO}_{3}, 2.0-14.5$ mol. per cent $\mathrm{MgCO}_{3}$, and 0.2-6.5 mol. per cent $(\mathrm{Fe}+\mathrm{Mn}) \mathrm{Co}_{3}$ (Figure 4). As a whole they are rich in $\mathrm{FeCO}_{3}$ and poor in $\mathrm{MgCO}_{3}$ compared with the Pleistocene high $\mathrm{Mg}$ calcite. Sparry calcite cements of the uppermost Oligocene sandstone have a chemical composition within the range of 94.0 to $98.5 \mathrm{~mol}$. per cent $\mathrm{CaCO}_{3}, 0.5$ to $3.0 \mathrm{~mol}$. per cent $\mathrm{MgCO}_{3}$, and 1.0 to $4.5 \mathrm{~mol}$. per cent $(\mathrm{Fe}+\mathrm{Mn})$ $\mathrm{CO}_{3}$, showing the least substitution of $\mathrm{Ca}$ by $\mathrm{Mg}, \mathrm{Fe}$, and $\mathrm{Mn}$. In Sample 439-28-3 the content of $\mathrm{FeCO}_{3}$ is roughly equal to that of $\mathrm{MgCO}_{3}$, but in deeper samples such as 439-30-3, 439-31-4, and 439-32-1, $\mathrm{FeCO}_{3}$ exceeds $\mathrm{MgCO}_{3}$.

\section{Biogenic Calcite}

Biogenic calcite has a narrower range of composition than authigenic calcite, containing 95.0 to $99.8 \mathrm{~mol}$. per cent $\mathrm{CaCO}_{3}, 0.8$ to $5.0 \mathrm{~mol}$. per cent $\mathrm{MgCO}_{3}$, and trace -0.8 mol. per cent $(\mathrm{Fe}+\mathrm{Mn}) \mathrm{CO}_{3}$, as shown in Figure 5 . It seems to be practically unchanged in composition during burial diagenesis down to approximately 1000 meters and to maintain its initial chemical composition in spite of notable changes in the composition of authigenic calcite. This is supported by the common occurrence of well-preserved calcareous shells.

\section{Detrital Calcite}

Detrital calcite grains in the uppermost Oligocene sandstone tend to concentrate near the end member composition and contain mainly 98.2 to $99.8 \mathrm{~mol}$. per cent $\mathrm{CaCO}_{3}$, rarely down to $96.7 \mathrm{~mol}$. per cent, 0.3 to $1.2 \mathrm{~mol}$. per cent $\mathrm{MgCO}_{3}$, and trace $-1.3 \mathrm{~mol}$. per cent $(\mathrm{Fe}+\mathrm{Mn}) \mathrm{CO}_{3}$, rarely up to $2.8 \mathrm{~mol}$. per cent. We noticed no significant difference in composition between micritic limestone clasts and sparry calcite clasts.

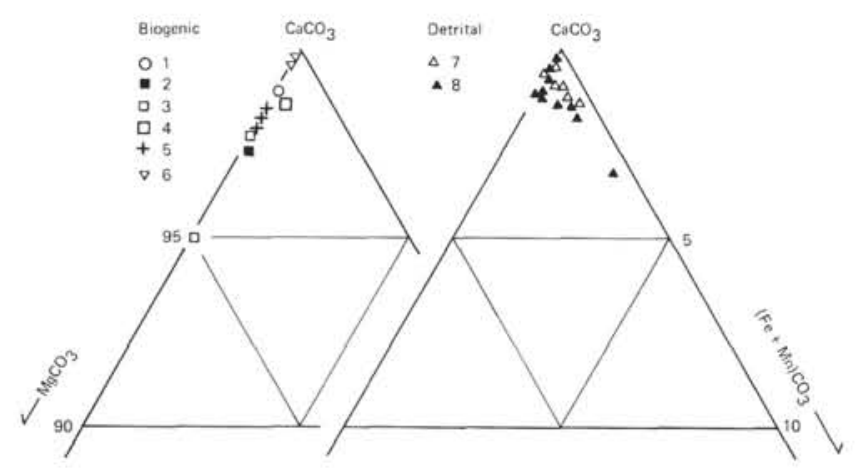

Figure 5. Chemical composition of biogenic and detrital calcites. (1. Test of planktonic foraminifers, Sample $438 \mathrm{~A}-3-6,134-136 \mathrm{~cm} ; 2$. test of planktonic foraminifers, Sample 438A-60-1, 94-96 cm; 3. test of benthic foraminifers, Sample 438A-68-2, 24-26 cm; 4. test of planktonic foraminifers, Sample 439-11, CC; 5. echinoid spines, Sample 439-14-3, 40-43 cm; 6. shell fragment of pelecypod, Sample 439-26-3, 5-7 $\mathrm{cm}$; 7. detrital calcite, Sample 439-31-4, 43-45 cm; 8. detrital calcite, Sample 439-32-1, 99-101 cm.)

\section{Authigenic Dolomite}

Rhombohedral dolomite forming poikilitic texture along with sparry calcite is highly calcian, with a composition within the range of 59.8 to $63.3 \mathrm{~mol}$. per cent $\mathrm{CaCO}_{3}, 36.5$ to $40.2 \mathrm{~mol}$. per cent $\mathrm{MgCO}_{3}$, and trace -0.3 mol. per cent $(\mathrm{Fe}+\mathrm{Mn}) \mathrm{CO}_{3}$, as shown in Figure 6 . We observed no variation in composition across single crystals.

\section{Detrital Dolomite and Ankerite}

Detrital "dolomite" covers a wide compositional field of $\mathrm{Ca}$ dolomite, $\mathrm{CaFe}$ dolomite, and $\mathrm{Ca}$ ankerite, possessing 51.5 to $58.8 \mathrm{~mol}$. per cent $\mathrm{CaCO}_{3}, 31.5$ to $45.3 \mathrm{~mol}$. per cent $\mathrm{MgCO}_{3}$, and trace-14.6 mol. per cent $(\mathrm{Fe}+\mathrm{Mn}) \mathrm{CO}_{3}$-as shown in Figure 6. Compositional zoning across single grains often occurs. The core of grains is depleted in $\mathrm{FeCO}_{3}$, which increases suddenly at the rim by as much as $15 \mathrm{~mol}$. per cent, as shown in beam scanning profiles of Figure 7. X-ray image photomicrographs have revealed that zoned detrital "dolomite" is made up of anhedral Ca dolomite core and 10 - to 25-mm-thick overgrowth of CaFe dolomite or $\mathrm{Ca}$ ankerite (Figure 8). Such a zoned "dolomite" was reported from the Upper Cretaceous flysch deposits in the Northern Apennines in Italy by Scholle (1971). Judging from the rhombohedral shape, appearance, and internal structure, detrital "dolomite" grains are assumed to have been transported a rather short distance during and after the overgrowth of $\mathrm{Ca}$ ankerite or $\mathrm{CaFe}$ dolomite.

"Dolomite" replacing(?) chert and siliceous shale is as a whole highly ferroan, ranging 53.1 to $56.1 \mathrm{~mol}$. per cent $\mathrm{CaCO}_{3}, 26.5$ to 40.5 mol. per cent $\mathrm{MgCO}_{3}$, and 4.2 to $18.1 \mathrm{~mol}$. per cent $(\mathrm{Fe}+\mathrm{Mn}) \mathrm{CO}_{3}$. There is compositional zoning in some grains in which the rim is more ferroan than the core, as in the case of the aforementioned large detrital "dolomite" grains.

\section{CARBONATE DIAGENESIS AND DOLOMITIZATION}

\section{Precipitation of High Mg Calcite}

It is not clear whether the bladed high $\mathrm{Mg}$ calcite cements in the Pleistocene sediments were precipitated on sea floor or in sediments, though precipitation probably occurred beneath the sea water/sediment interface. Its striking resemblances in appearance to the scalanohedral calcite cement of the Jamaican reefs (Land and Goreau, 1970) and in composition to the fine-grained authigenic calcite of the eastern Mediterranean deep sea sediments (Milliman and Müller, 1974) supports the early precipitation of the bladed calcite. Glover and Sippel (1967) and Alexandersson (1972) have also mentioned that high $\mathrm{Mg}$ calcite is likely to be precipitated from sea water. Some high $\mathrm{Mg}$ calcite cement on the sea floor is assumed to have been precipitated by high temperature and high salinity (Milliman and Müller, 1973). Schlager and James (1978) have found low $\mathrm{Mg}$ calcite cements with 3.5 to $5 \mathrm{~mol}$. per cent $\mathrm{MgCO}_{3}$ in the Tongue of Ocean, Bahama, and attributed the low $\mathrm{MgCO}_{3}$ to cold bottom waters. They stated, "Magnesian calcites with 


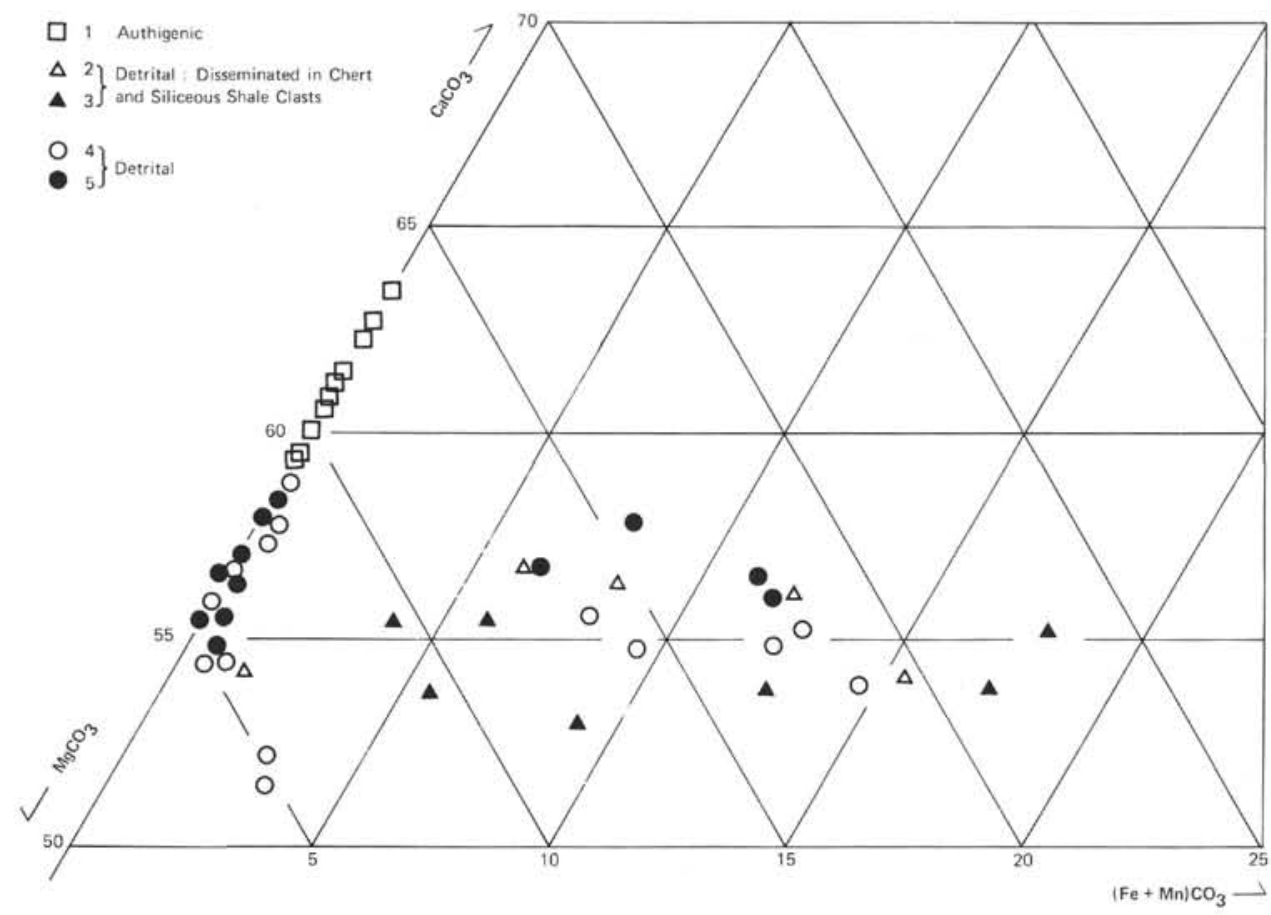

Figure 6. Chemical composition of authigenic and detrital "dolomite." (1. Rhombohedral dolomite cementing sandstone, Sample 439-28-3, 124-125 cm; 2, 3. rhombohedral "dolomite" replacing chert and siliceous shale clasts, Sample 439-30-3, 15-18 cm (2), and Sample 439-32-1, 99-101 cm (3); 4, 5. detrital "dolomite" Sample 439-30-1, 10-12 cm (4), and Sample 439-32-1, 99-101 cm (5). Ankerite composition, $\mathrm{Mg}: \mathrm{Fe}>4$, is always encountered at the rim of detrital and replacement "dolomite.")
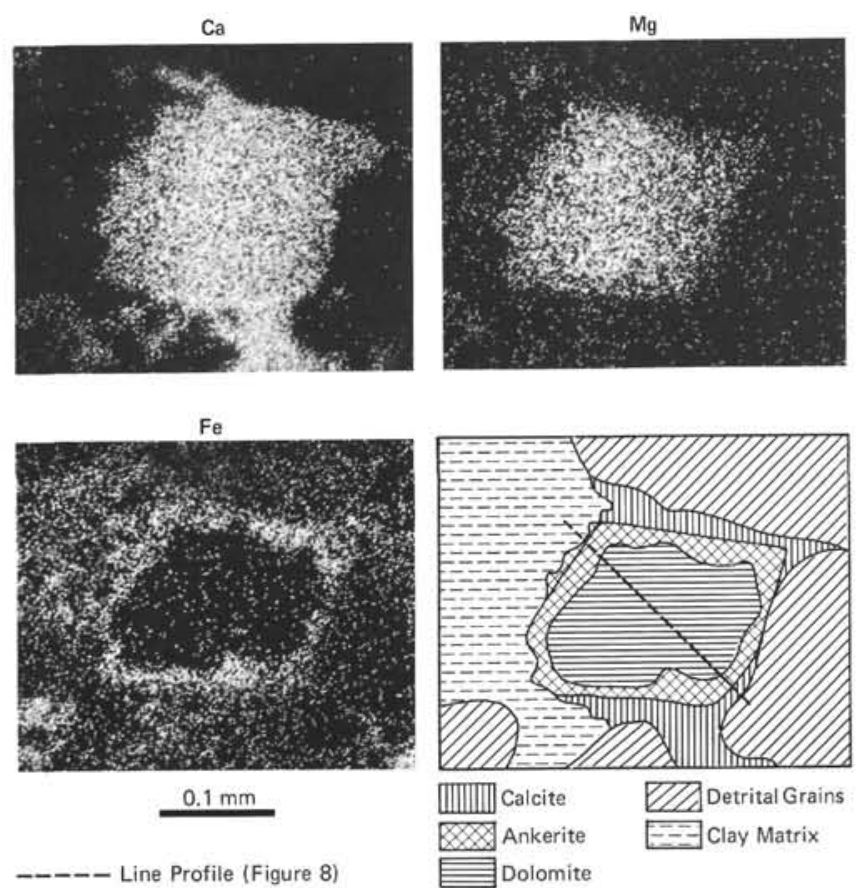

Figure 7. X-ray photomicrographs on a detrital "dolomite" crystal, Sample 439-32-1, 99-101 cm, showing dolomite core, ankerite overgrowth, and syntaxial calcite cement. 


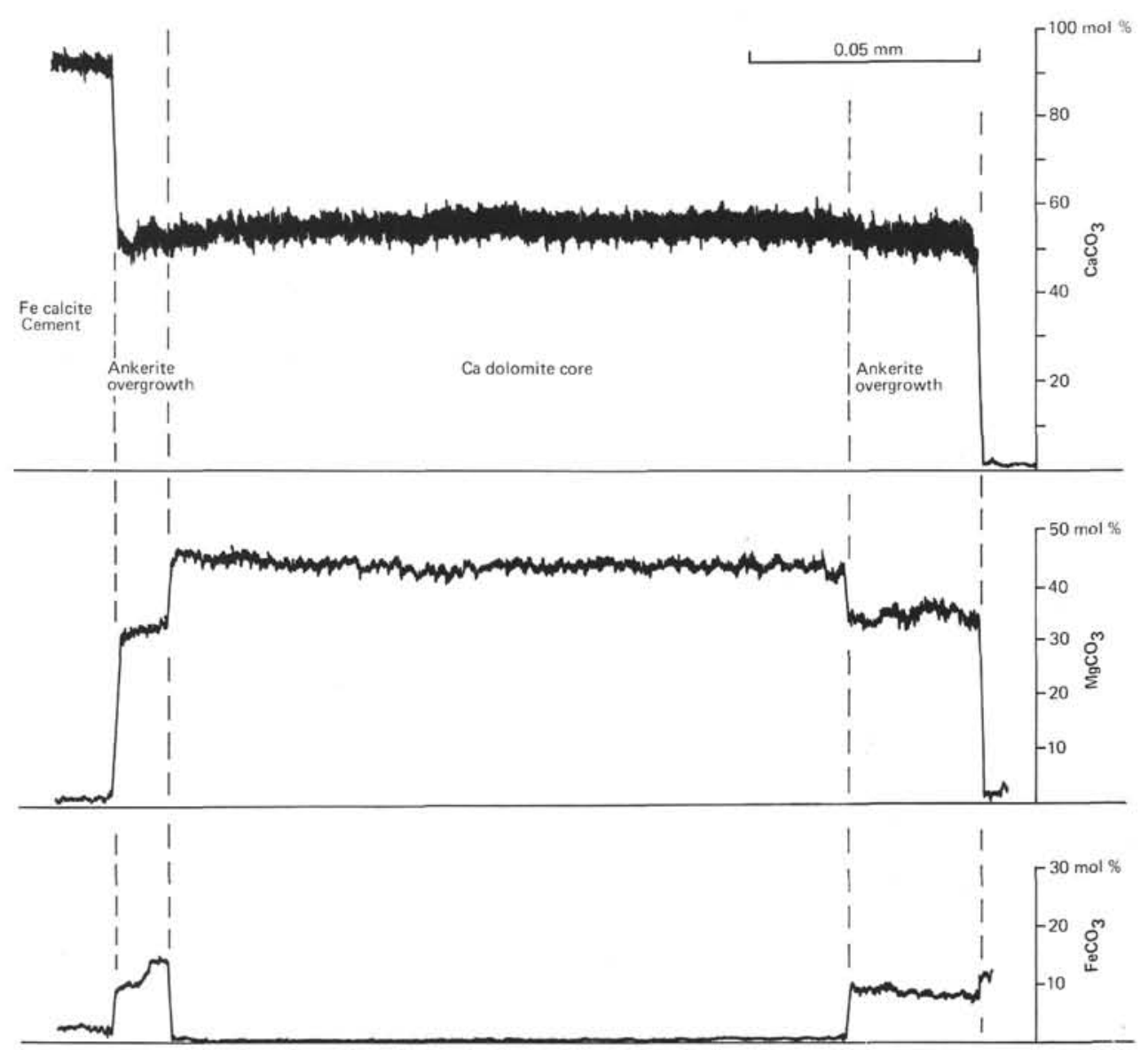

Figure 8. X-ray beam scanning profiles on a detrital "dolomite" crystal in Fig. 7. (Beam scanning speed was $0.02 \mathrm{~mm} / \mathrm{min}$. $\mathrm{MgCO}$ and $\mathrm{FeCO}_{3}$ content changes suddenly, not gradually, at the rim.)

more than 10 mol. per cent $\mathrm{MgCO}_{3}$ tend to occur in waters less than 1000 meters deep, that is, in the surface and intermediate waters." However, at Site 438, high $\mathrm{Mg}$ calcite cements with up to $12 \mathrm{~mol}$. per cent $\mathrm{MgCO}_{3}$ are contained in lower to lower middle bathyal sediments, which does not indicate extraordinarily high salinity and temperature. This phenomenon suggests that high $\mathrm{Mg}$ calcite can be formed in a normal marine environment. Pleistocene sediments have numerous ash layers and contain a significant amount of volcanic rock fragments and glass shards, the latter sometimes replaced by high $\mathrm{Mg}$ calcite. This may indicate that volcanic glass had an important part in the formation of high $\mathrm{Mg}$ calcite in the normal marine environment. Authigenic calcite replacing volcanic glass has been reported from deep sea bottom sediments in the South Pacific by Bonatti (1967).

\section{Transformation of High $\mathrm{Mg}$ Calcite into $\mathrm{FeMg}$ and $\mathrm{Fe}$ Calcites}

Authigenic calcites in the Miocene sediments range in composition from high $\mathrm{Mg}$ calcite with $14 \mathrm{~mol}$. per cent $\mathrm{MgCO}_{3}$ to $\mathrm{Fe}$ calcite with $7 \mathrm{~mol}$. per cent $\mathrm{FeCO}_{3}$ through $\mathrm{FeMg}$ calcite. They usually occur in diatomaceous clay and claystone associated with glass shards and volcanic rock fragments, as in the case of the Pleistocene bladed high $\mathrm{Mg}$ calcite cements. Though bladed crystals were not recognized in the Miocene carbonate sediments, irregularly shaped polyhedral and a few rhombohedral calcite grains of a similar size as the bladed crystals were observed with the help of SEM. Hence it is probable that $\mathrm{FeMg}$ and $\mathrm{Fe}$ calcites in the Miocene sediments were initially precipitated as high $\mathrm{Mg}$ calcite at a shallower depth. High $\mathrm{Mg}$ calcite was then transformed into $\mathrm{FeMg}$ or $\mathrm{Fe}$ calcite in the course of burial diagenesis, probably owing to a decrease of $\mathrm{Mg}^{2+}$ ions in the interstitial water, as reported at the other sites of this volume; an increase of $\mathrm{Fe}^{2+}$ ions; or a rise of temperature at deeper levels. Temperature measurements by means of HRT (high resolution temperature tool) range from $24^{\circ} \mathrm{C}$ to $26^{\circ} \mathrm{C}$ at the bottom of the holes. Moreover, it may be deduced that dolomitization was caused by $\mathrm{Mg}^{2+}$ ions released from high $\mathrm{Mg}$ calcite during this transformation. In fact, minor amounts of "dolomite" were rarely detected in the Miocene carbonate sediments. It is interesting that Nash and Pittman (1975) observed a decrease of calcite content and an increase of dolomite content with increasing depth in the PlioPleistocene sediments off Trinidad.

\section{Origin of $\mathrm{Fe}$ Calcite and $\mathrm{Ca}$ Dolomite in the Uppermost Oligocene Sandstone}

Matsumoto (1978) has revealed the sequence and approximate depth of the formation of authigenic carbon- 
ates such as calcite, dolomite, ankerite, siderite, and magnesite of various chemical composition in the marine, brackish, and fresh water sediments in the Paleogene Ishikari coalfield about $300 \mathrm{~km}$ north of Sites 438 and 439 (Figure 1). According to Matsumoto, carbonate cementation in the Oligocene marine sediments begins with the precipitation of high $\mathrm{Mg}$ calcite, which forms concretions, lenses, or bands. The depth of formation is estimated to be less than 300 meters, and probably a few tens of meters, on the basis of the minus cement porosity of carbonate rocks. Calcitic concretions in various geologic ages are generally considered to have been formed at very shallow depth before significant compaction (Weeks, 1957; Raiswell, 1971).

Synthetic calcite in sea water is always high $\mathrm{Mg}$ type, containing up to $14 \mathrm{~mol}$. per cent $\mathrm{MgCO}_{3}$ (Glover and Sippel, 1967). These lines of evidence suggest that the carbonate cement of the uppermost Oligocene sandstone has been precipitated initially as high $\mathrm{Mg}$ calcite, not as $\mathrm{Fe}$ or $\mathrm{FeMg}$ calcite. Thereafter high $\mathrm{Mg}$ calcite was transformed into $\mathrm{FeMg}$ calcite, $\mathrm{Fe}$ calcite, or Ca dolomite. The transformation and dolomitization in the uppermost Oligocene sandstone can be explained in two ways: (1) changes in the physicochemical conditions, such as chemical composition of interstitial water and temperature with increasing depth, as in the case of the Miocene calcite; or (2) influences of fresh or brackish water during burial.

Chemical composition of authigenic calcite ranges from the Pleistocene high $\mathrm{Mg}$ calcite to the Oligocene $\mathrm{Fe}$ calcite through the Miocene FeMg calcite. Even in the Oligocene sandstone, deeper samples contain more iron and less magnesium. Ca dolomite cements are recognized exclusively in Sample 439-28-3, which contains abundant authigenic calcite, whereas the other Oligocene samples have little or no authigenic calcite and do not contain authigenic dolomite. These phenomena support the first explanation as to the origin of $\mathrm{Fe}$ calcite and $\mathrm{Ca}$ dolomite.

The second explanation is suggested by the salinity record and the change in a depositional environment at Sites 438 and 439 . Salinity of interstitial water at Sites 438 and 439 shows gradual decline with depth from 35 parts per mill in the shallowest core to 19 parts per mill in the deepest core, as reported at the other sites of this volume. This decline can be interpreted as due to migration and mixing of fresh or brackish water from the subaerially formed dacitic boulder conglomerate at the base of the sequence and/or by a recharge of meteoric water through the permeable Oligocene sand from the subaerially exposed nearby Oyashio ancient landmass at the early stage of diagenesis. According to Matsumoto (1978), the precipitation of authigenic carbonates in the Paleogene strata is considered to have been controlled both by the initial sedimentary facies and by the migration and mixing of interstitial waters between saline water sediments and fresh water ones during burial. In marine and brackish water sediments of coal measures, ankerite and dolomite are precipitated at some hundred meters depth following the precursor high $\mathrm{Mg}$ and $\mathrm{FeMg}$ calcites due to mixing of interstitial waters. In re- cent years dolomitization is thought to be caused not only by a high salinity water with high $\mathrm{Mg}^{2}+/ \mathrm{Ca}^{2+}$ ratio but also by a mixing of saline water and fresh water (Badiozamani, 1973; Land, 1973; and Folk and Land, 1975). Moreover, well-crystallized calcite and dolomite usually occur in permeable sandstone rather than in impermeable claystone and siltstone. These observations all suggest that the formation of $\mathrm{Fe}$ calcite and $\mathrm{Ca}$ dolomite occurred under the influence of migrating fresh or brackish water. At present we do not have any persuasive evidence to determine which explanation more correctly interprets the occurrence of $\mathrm{Fe}$ calcite and $\mathrm{Ca}$ dolomite in the uppermost Oligocene sandstone, though we are inclined to conclude that the transformation of calcite and dolomitization were accelerated by the migration and mixing of fresh or brackish water in the course of burial diagenesis.

\section{ACKNOWLEDGMENTS}

Professor N. Nasu of the Ocean Research Institute, the University of Tokyo, kindly permitted us to utilize his collection of the DSDP/IPOD core samples. He and Professor R. E. Garrison of the University of California at Santa Cruz reviewed the manuscript. Professor K. Konishi of the Kanazawa University determined echinoid spines. Mr. K. Fujioka helped us to select samples and offered valuable information on shipboard scientific results. Mr. Y. Kakuwa helped us to operate a scanning electron microscope. We express our gratitudes to them all.

\section{REFERENCES}

Alexandersson, T., 1972. Mediterranean beach rock cementation: Marine precipitation of Mg-calcite. In Sanley, D. J. (Ed.), In the Mediterranean Sea (Strondsburg), pp. 203-224.

Badiozamani, K., 1973. The Dorag dolomitization modelapplication to the middle Ordovician of Wisconsin. J. Sediment Petrol., 43, 965-984.

Bence, A. E., and Albee, A. L., 1968. Empirical correction factors for the electron microprobe analysis of silicates and oxides. J. Geol., 76, 382-403.

Bonatti, E., 1967. Deep-sea authigenic calcite and dolomite. Science, 153 (No. 3735), 534-537.

Fischer, A. G., and Garrison, R. E., 1967. Carbonate lithification on the sea floor. J. Geol., 75, 488-496.

Folk, R. L., and Land, L. S., 1975. Mg/Ca ratio and salinity: Two controls over crystallization of dolomite. Am. Assoc. Petrol. Geol., 59, 60-68.

Glover, E. D., and Sippel, R. E., 1967. Synthesis of magnesium calcites. Geochim. Cosmoshim. Acta, 31, 603-613.

Land, L. S., 1973. Contemporaneous dolomitization of Middle Pleistocene reefs by meteoric water, North Jamaica. Coral Reef Projects. Bull. Mar. Sci., 23, 64-92.

Land, L. S., and Goreau, T. S., 1970. Submarine lithification of Jamaican Reefs. J. Sed. Petrol., 38, 458-462.

Marshall, J. F., and Davies, P. J., 1975. High magnesian calcite ooids from the Great Barrier Reef. J. Sediment Petrol., 45, p. 285-291.

Matsumoto, R., 1978. Occurrence and origin of authigenic Ca$\mathrm{Mg}-\mathrm{Fe}$ carbonates and carbonate rocks in the Paleogene coalfield regions in Japan. J. Fac. Sci. Univ. Tokyo [II], $20,336-367$.

Milliman, J. D., 1974. Recent Sedimentary Carbonates, Part I: Marine Carbonates: New York (Springer-Verlag), p. 376. 
Milliman, J. D., and Müller, J., 1973. Precipitation and lithification of magnesian calcite in the deep-sea sediments of the eastern Mediterranean Sea. Sedimentology, 20, 2945 .

Nash, A. J., and Pittman, E. D., 1975. Ferro-magnesian calcite cement in sandstone. J. Sediment Petrol., 45, 258-265.

Pettijohn, F. J., Potter, P. E., and Siever, R., 1972. Sand and Sandstone: New York (Springer-Verlag), p. 618.

Raiswell, R., 1971. The growth of Cambrian and Liassic Concretions. Sedimentology, 17, 147-171.
Schlager, W., and James, N. P., 1978. Low-magnesian calcite limestones forming at the deep-sea floor, Tongue of the Ocean, Bahamas. Sedimentology, 25, 675-702.

Scholle, P. A., 1971. Diagenesis of deep-water carbonate turbidites, Upper Cretaceous Monte Antola flysch, Northern Apennines, Italy. J. Sediment Petrol., 41, 233-250.

Thompson, G., and Bowen, V. T., 1969. Analyses of coccolith ooze from the deep tropical Atlantic. J. Mar. Res., 27, 28-38.

Weeks, L. G., 1957. Origin of carbonate concretions in shales, Magdalena Valley, Columbia. Bull. Geol. Soc. Am., 68, 95-102. 


\section{PLATE 1}

Thin Section Photomicrographs of Carbonate Sediments Figures 1, 3, 5, and 7: plane light; Figures 2, 4, 6, and 8: cross-polarized light. Scale bar $=100 \mu \mathrm{m}$.

Figures 1, 2 Rhombohedral dolomite and sparry calcite cement forming a poikilitic texture in sandstone, Sample 439-28-3, 124-125 cm (upper Oligocene). Authigenic dolomite is always much smaller than detrital "dolomite."

Figures 3, 4 Detrital "dolomite" in sandstone, Sample 439-30-3, $15-18 \mathrm{~cm}$ (upper Oligocene). Detrital "dolomite" is easily distinguished from authigenic dolomite by its broken shape, worn appearance, and crystal size. Detrital "dolomite" crystals are similar in size to the other components of sandstone and much larger than authigenic dolomite.

Figures 5, 6 Micritic limestone clasts and sparry calcite grain, Sample 439-30-3, 15-18 cm (upper Oligocene). Detrital calcite grains generally amount to 4 to 5 per cent by volume in the Oligocene sandstone.

Figures 7, 8 Angular chert grains associated with "dolomite" rhombohedra, Sample 439-30-3, 15-18 cm (upper Oligocene). "Dolomite" replaces only chert and siliceous shale, not the other components of sandstone. 
PLATE 1
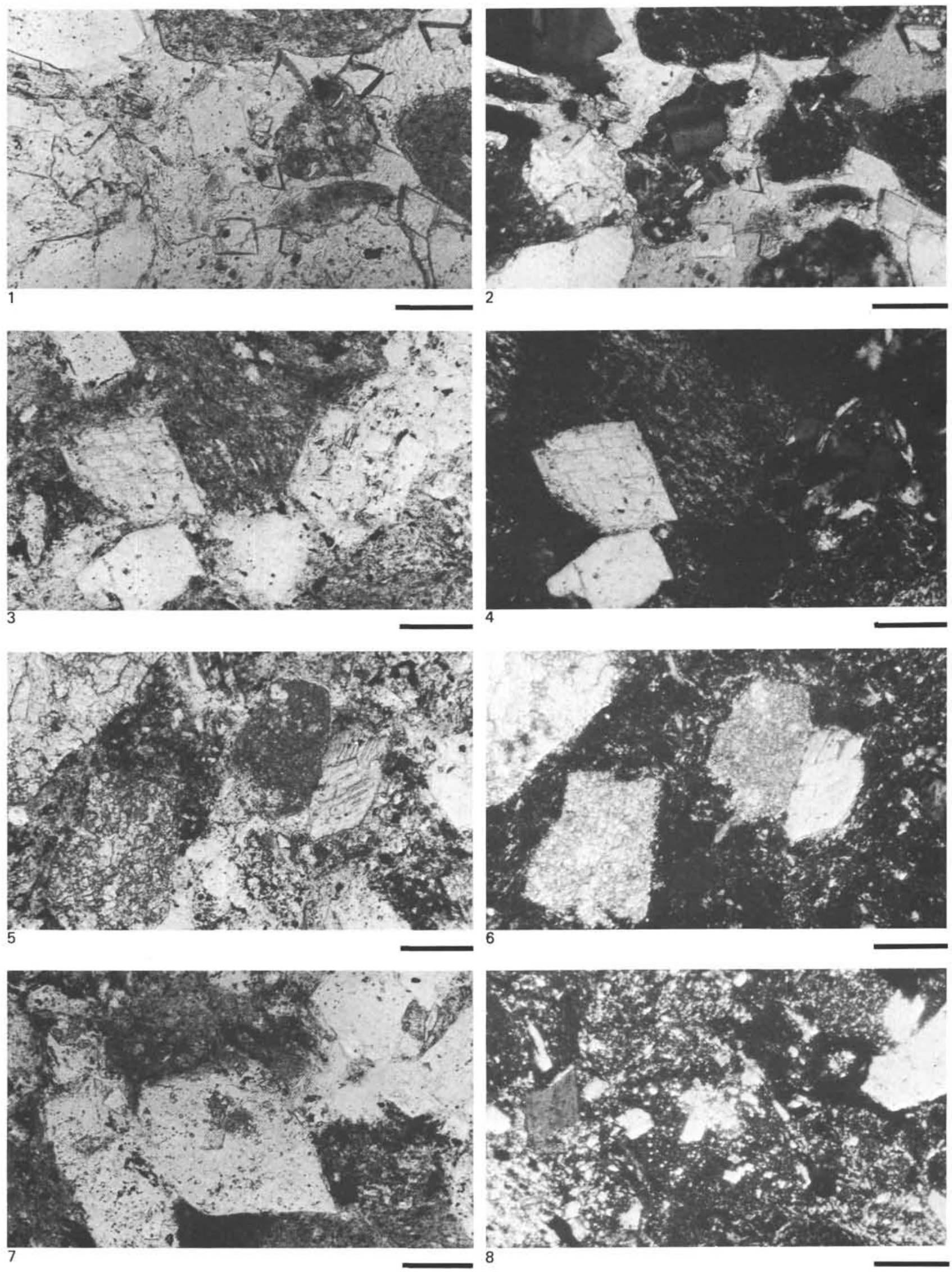


\section{PLATE 2}

\section{SEM Photomicrographs of Carbonate Sediments}

Figure 1 Biogenic calcite, Sample 438A-26-3, 60-62 cm (Pliocene). Well- to moderately preserved coccoliths are common. In general, Type A carbonate sediments contain significant amounts of biogenic calcite such as foraminiferal tests and/or coccoliths. Scale bar $=10 \mu \mathrm{m}$.

Figure 2 Enlarged view of the coccoliths in Figure 1. Scale bar $=5 \mu \mathrm{m}$.

Figure 3 Bladed high Mg calcite crystals, Sample 438A-3-6, $134-136 \mathrm{~cm}$ (Pleistocene). Bladed crystals usually fill interstices but rarely replace glass shards. Crystal twins are not uncommon. Scale bar $=50 \mu \mathrm{m}$.

Figure $4 \quad$ Enlarged view of the bladed calcite crystals in Figure 3. Scale bar $=10 \mu \mathrm{m}$.

Figure $5 \quad$ Authigenic dolomite, Sample 439-28-3, 124-125 $\mathrm{cm}$ (upper Oligocene). Euhedral crystals are fresh in appearance and often contain twins. Scale bar $=20 \mu \mathrm{m}$.

Figure 6 Detrital "dolomite", Sample 439-31-4, 43-45 cm (upper Oligocene). Detrital "dolomite" crystals are usually broken and worn in appearance. Scale bar $=100 \mu \mathrm{m}$. 
PLATE 2
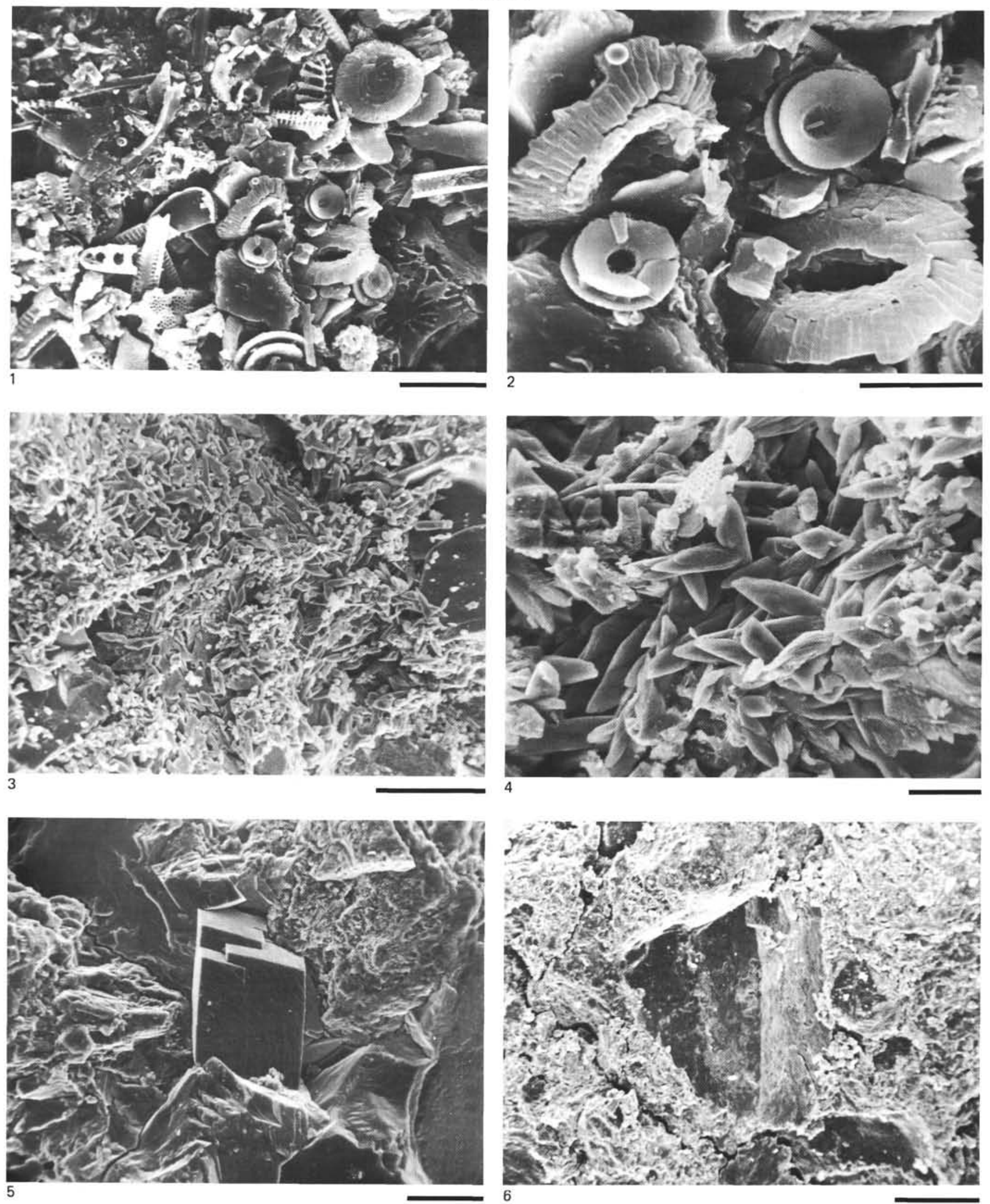